\title{
TRENDS AND CHALLENGES OF ROMANIAN BROKERAGE INSURANCE MARKET
}

\author{
Dan Constantin Dănulețiu ${ }^{l}$ \\ Adina Elena Dănulețiu²
}

\begin{abstract}
The distribution of insurance products represents a key aspect regarding the attainment of positive results by insurers. Insurance brokers represent one of the major distribution channels in some national markets, including Romania. The present paper aims at highlighting the importance of insurance brokerage on the Romanian market, analyzing the evolution of brokers in quantitative terms and also grasping the main characteristics of the recent evolution of this market. Based on the official statistics, the paper emphasizes the main managerial aspects that have guided and will guide the Romanian brokerage market, as well as the challenges brokers will have to solve in order to have a positive development.
\end{abstract}

Key words: insurance, brokers, distribution channels

JEL codes: $G 22$

\section{Introduction}

Faced with the effects of the economic and financial crisis, the insurers operating on the Romanian market had to find optimal development solutions for their own business and the distribution of insurance products represent a key aspect in this regard.

In Romania, the distribution of insurances can be achieved in two basic ways:

- direct distribution, achieved through the employees of the insurance company or information technologies;

- distribution through intermediaries which includes three major categories of entities: exclusive insurance agents who may sell the products of only one insurer; brokers who can sell the products of several insurers, mainly acting as representatives of the potential insured; and the banks through bancassurance.

The importance of the insurance brokerage within the Romanian insurance market, as a consequence of the functions and role they have, requires an adequate study of both the quantitative aspects of the insurance brokerage market and of the qualitative, managerial aspects.

Given this fact, the paper aims to conduct an analysis of the recent developments of the brokerage on the Romanian insurance market identifying its trends and trying to observe the effects the economic and financial crisis has produced therein. There will also be analyzed the aspects brokers will have to face in the future both in terms of legislative changes and in terms of forecasted development of the insurance market.

\section{Literature review}

The insurance literature provides some insights regarding the field of insurance brokers or the wider field of insurance intermediaries.

Within this literature, a series of papers is focused on outlining the functions and the role of the intermediaries and particularly of the insurance brokers. Thus, it is emphasized that the main function of intermediaries is to ensure the congruence between the particular needs of the potential

1 „1Decembrie 1918” University of Alba Iulia, Romania, e-mail: dan.danuletiu@gmail.com

2 „1Decembrie 1918” University of Alba Iulia, Romania, e-mail: adina.danuletiu”gmail.com 
clients and the insurers' products (Cummings and Doherty, 2006; M. Eckardt, 2007) and the effects are reflected in reducing the searching costs for the potential clients, in reducing the adverse selection problems due to the fact that the intermediaries, recognized as the market's professionals, succeed in providing the necessary information to their clients, therefore the clients will get the best coverage in terms of risk and, in many cases, in reducing the premiums paid for the insurance.

Most of the insurance literature shows that the development of the insurance market generated the growth of the activity of the insurance intermediaries, and especially of the brokers, by inclusion of a series of new activities such as risk management (Funk, 2002, BIPAR, 2010, Mass, 2010) or damage management (BIPAR, 2010). Thus, especially the intermediaries for the commercial insurance agents become the partners for the insured firms, helping them to solve problems (Mass, 2010).

A study conducted by the United Nations (2007) reflects another effect generated by the activity of insurance intermediaries, especially brokers - the build up of a more competitive insurance market, with improved products. Thus, the better information the clients will have about the insurance products and the complete identification of the risks they are subjected will increase the knowledge of insurance products' consumers. This implicitly will increase the demand for such products, but also will improve the insurance products as a consequence of better informed consumers.

In a study on commercial insurance, Swiss Re points out that the insurance brokers also provide a range of services for insurers such as assistance for brokers in modeling the risks and in the field of actuarial calculations, in assets management, as well as in the field of indemnities (SIGMA, 2004).

A synthesis of the insurance intermediaries' role is given in the "Insurance Intermediaries in Europe" report prepared for BIPAR by London Economics (2010), which specifies that the intermediaries help clients by: identifying the risks faced by the clients; providing the necessary information so the clients can make a decision; establishing new and innovative solutions; reducing the clients' searching costs; providing assistance for clients; assisting the clients in matters related to indemnities.

Other issues addressed by the insurance literature refer to the quality of the provided information, to the relation between the way of establishing the brokers' commission and the conflict of interest when giving advices, the type of clients and the offered insurance forms and brokers' size.

Cummings and Doherty (2006), analyzing the US brokerage market point out that the nature of competition on the market of insurance brokerage is based more on quality than on the price of services. On this basis, the authors suggest that for low to medium-sized risks the competition is very high among brokers as the providers of specific services are both the large and very large brokers, but also the small ones. On the other hand, certain risks are exclusively covered by very large brokers due to their expertise capacity and financial power.

Eckardt (2002) shows that the information the intermediaries provide have two dimensions: an objective dimension, related to the product's characteristics and their suitability to the purpose for which it was created, and a subjective dimension, related to the transmission of the objective information so that it results in choosing the best solution by the client. Comparing the quality of the information provided by agents, respectively brokers, the author finds that brokers provide information and consulting services superior to those provided by the insurance agents; but in a more recent study, Eckardt and Rathke-Doppner (2008) show that the quality of insurance intermediation depends not only on the intermediation form - exclusive agents or brokers, but also on the individual activities of obtaining and processing the information.

However, the quality of the provided information may be affected by the commissions charged by brokers from insurers and other incentives that a certain insurer may give to the broker, as it was forewarned in the European Commission's Report on insurance (2007). The solution 
suggested in this document regards the disclosure of the potential conflicts of interests which the broker has in providing assistance and especially the disclosure of the size of the commissions. In this respect, Focht et all. (2009) suggest that an analysis of the brokerage must consider the issue of incentives for brokers and states that insurance companies must give additional commissions based on performance in order not to lose market share as a result of a lower interest of brokers for acceding to the products of the respective company. On the other hand, the authors do not think that the disclosure of commission charged by brokers would lead to a better outcome for clients. An approach of the insurance brokers' opportunism is performed by Tajudeen (2011), who shows that such a problem is present on the insurance market in Nigeria and suggests that it could be reduced by establishing the broker's remuneration.

In terms of legislative elements on insurance brokerage, Braunwarth and others (2009) highlight the impact of the Insurance Mediation Directive and of the German legislation concerning this matter in the field of clients relations management, emphasizing that the requests for documentation regarding the clients should not be seen as a source of costs, but as having the potential to lead to additional revenue.

Studies on the quantitative evolution of the brokerage markets were conducted by profile bodies or by participants in the international insurance market (Swiss Re, 2004; CEA, 2010; BIPAR, 2010), as well as in some specialty papers (Cummings and Doherty, 2006).

Regarding the brokerage activity in Romania, it was tackled by Dănulețiu and Dănulețiu (2008) and Gavriletea (2008).

Dănulețiu and Dănulețiu (2008) highlight the legislative developments that have guided the activity of the Romanian brokers during 1990-2007, showing the impact that the accession to the European Union had on legislation. It has also emphasized the effects on the market in terms of the number of brokers as a consequence of the potential entry on the market of the brokers from the European Economic Area, as a consequence of the principles of freedom to provide services or freedom of establishment. Gavriletea (2008) emphasizes the particularities of selling channels of insurance companies in Romania, focusing on the most important: brokers, agents, employed inspectors, direct answers, multi-channel distribution system, stressing on the advantages and disadvantages of using brokers.

\section{Research methodology}

The research is based on reviewing the main legislative issues affecting the business of insurance brokers during 2008-2010, but also on the statistical analysis of data regarding the insurance brokerage market in Romania by comparing its indicators with relevant markets in Europe, and by highlighting their evolutions during 2008-2010 on the Romanian insurance market.

In order to emphasize the qualitative aspects referring to the strategies of the brokerage companies we mainly used the interviews given in the specialized media by the leaders of these companies, and also the interventions of some of the market's representatives at specialized conferences. It was also highlighted the perception of the population regarding the broking activity in insurance, reflecting mainly the results of a study developed by IRES in the beginning of the year 2011.

Based on these analyses which are limited due to data limiting by the specialized institutions or by the market players, conclusions regarding the market's evolution will be drawn, and the main risks affecting this industry will be stressed.

\section{Legislative aspects of the insurance brokerage activity}

The insurance brokerage market in Romania was initially regulated by Law 47/1991, which gave the right of existence to these intermediaries category but has many regulatory gaps, and later by Law 32/2000, which followed a first harmonization with the EU requirements. After Romania was accepted as candidate country to EU, the National legislation begins the harmonization with the 
provisions of the community acquis in the field. Thus, a first effect of Romania's acceptance as a candidate was the creation of the Insurance Supervisory Commission as an autonomous body responsible for drafting the secondary legislation in the field of insurance and supervising this market. The opening of negotiations on Chapter 3 - "Freedom to provide services" was made on 20 December 2002, when for regulating the insurance intermediation has appeared the Directive 2002/92/CE, through which rules regarding the access to insurance and reinsurance intermediation activities and by exercising these rules by individuals or companies settled or wishing to settle in member state were determined. As a result, the Romanian legislation regulated the right of establishment and the freedom to provide services based on the unique licence for insurance intermediaries and it also took the provisions of the directive referring to insurance intermediaries whose application will result in increased professionalism of those who come in contact with policyholders and potential policyholders and thus will contribute to the qualitative development of the services for products offered by insurers.

Subsequently, the legislation was improved, but it should be showed that during 2007-2010 the regulations aiming this area made references mainly to the protection of consumers of insurance products.

Thus, among the aspects regulated by the Insurance Supervisory Commission in this period were those related to:

- the register of intermediaries in insurances and/or reinsurances which provides a formal order of persons carrying out insurance activities through brokers;

- solving complaints regarding the activity of insurers, reinsurers and insurance and/or reinsurance intermediaries;

- the archive activity at insurers, reinsurers and insurance and/or reinsurance intermediaries;

- professional qualification and continuous training of persons working in the distribution of insurance products;

- the information that the insurers and insurers intermediaries are required to provide to clients and other elements that must be included in the insurance contract.

In addition, new regulations regarding the authorization of insurance and/or reinsurance brokers were issued and also the conditions to maintain this authorization, the right to settle and the freedom to provide services in Romania by insurance/reinsurance intermediaries authorized and/or registered by a competent authority in a EU member state, the shape and content of the financial and technical reports which insurance and/or reinsurance brokers are required to prepare. The provisions of these regulations included the prohibition of using the network selling system (multi level marketing) in the field of life and health insurance.

The desired and expected effect of these regulations is the development of an activity at a higher level in order to meet the needs of consumers as much as possible.

\section{Market analysis - results, critical elements}

The regulation of insurance intermediation took into consideration the importance this mechanism has in the distribution of insurance products. However, there is variation in market share of insurance distribution channels on the national markets of European countries, as reflected by the data in table 1.

Table no. 1

Total insurance distribution channels of national insurance markets during 2007-2009

\begin{tabular}{|l|c|c|c|c|c|c|c|c|c|}
\hline & \multicolumn{3}{|c|}{$\mathbf{2 0 0 7}$} & \multicolumn{3}{c|}{$\mathbf{2 0 0 8}$} & \multicolumn{3}{|c|}{$\mathbf{2 0 0 9}$} \\
\cline { 2 - 10 } & $\begin{array}{c}\text { Direct } \\
\text { sales }\end{array}$ & Brokers & Others & $\begin{array}{c}\text { Direct } \\
\text { sales }\end{array}$ & Brokers & Others & $\begin{array}{c}\text { Direct } \\
\text { sales }\end{array}$ & Brokers & Others \\
\hline $\begin{array}{l}\text { a)EU15 } \\
\text { countries }\end{array}$ & & & & & & & & & \\
\hline Austria & $25,90 \%$ & $22,50 \%$ & $51,60 \%$ & $25,90 \%$ & $24,00 \%$ & $50,10 \%$ & $20,80 \%$ & $21,60 \%$ & $57,60 \%$ \\
\hline Belgium & $19,80 \%$ & $42,40 \%$ & $37,80 \%$ & $19,60 \%$ & $43,10 \%$ & $37,30 \%$ & $19,40 \%$ & $43,30 \%$ & $37,30 \%$ \\
\hline
\end{tabular}




\begin{tabular}{|c|c|c|c|c|c|c|c|c|c|}
\hline Spain & $15,10 \%$ & $18,20 \%$ & $66,70 \%$ & $16,50 \%$ & $17,80 \%$ & $65,70 \%$ & n.a. & n.a. & n.a. \\
\hline France & $21,00 \%$ & $14,00 \%$ & $65,00 \%$ & $22,00 \%$ & $15,00 \%$ & $63,00 \%$ & $21,00 \%$ & $15,00 \%$ & $64,00 \%$ \\
\hline Italy & $9,40 \%$ & $3,70 \%$ & $86,90 \%$ & $10,00 \%$ & $4,00 \%$ & $86,00 \%$ & $7,90 \%$ & $3,20 \%$ & $88,90 \%$ \\
\hline Portugal & $6,10 \%$ & $5,80 \%$ & $88,10 \%$ & $7,40 \%$ & $5,60 \%$ & $87,00 \%$ & $4,70 \%$ & $6,10 \%$ & $89,20 \%$ \\
\hline $\begin{array}{l}\text { b) EU countries } \\
\text { acceded in } 2004 \\
\text { or } 2007\end{array}$ & & & & & & & & & \\
\hline Bulgaria & $27,50 \%$ & $30,60 \%$ & $41,90 \%$ & $21,40 \%$ & $37,40 \%$ & $41,20 \%$ & $19,40 \%$ & $42,70 \%$ & $37,90 \%$ \\
\hline Poland & $25,10 \%$ & $7,30 \%$ & $67,60 \%$ & $23,50 \%$ & $7,20 \%$ & $69,30 \%$ & $26,10 \%$ & $7,80 \%$ & $66,10 \%$ \\
\hline Slovenia & $15,20 \%$ & $11,90 \%$ & $72,90 \%$ & $13,60 \%$ & $13,30 \%$ & $73,10 \%$ & $20,10 \%$ & $6,10 \%$ & $73,80 \%$ \\
\hline Slovakia & n.a. & n.a. & n.a. & $16,00 \%$ & $4,40 \%$ & $79,60 \%$ & $29,00 \%$ & $3,00 \%$ & $68,00 \%$ \\
\hline Malta & n.a. & n.a. & n.a. & $14,30 \%$ & $9,90 \%$ & $75,80 \%$ & $12,90 \%$ & $9,20 \%$ & $77,90 \%$ \\
\hline $\begin{array}{l}\text { c) Non-EU } \\
\text { countries }\end{array}$ & & & & & & & & & \\
\hline Croatia & $60,20 \%$ & $1,80 \%$ & $38,00 \%$ & $60,70 \%$ & $2,00 \%$ & $37,30 \%$ & $63,90 \%$ & $1,90 \%$ & $34,20 \%$ \\
\hline Turkey & $9,90 \%$ & $8,70 \%$ & $81,40 \%$ & $8,50 \%$ & $9,20 \%$ & $82,30 \%$ & $9,80 \%$ & $9,80 \%$ & $80,40 \%$ \\
\hline
\end{tabular}

Note: "other" includes agents, bancassurance, etc.

Source: CEA statistics - http://www.cea.eu/index.php/facts-figures/statistical-series/market-operators, data not available for the year 2010

In the data available it can be seen that the insurance brokers have a very different importance in the mentioned countries. Thus, in countries like Belgium and Bulgaria, brokers are very important, in France and Spain their share is between $10 \%$ and 20\%, while in the other mentioned countries their share is below 10\%. Regarding the evolution of the market share in the three analyzed years, the only situations with continuous increases are the countries with important shares, the other countries recording sinusoidal evolutions. Such a situation is consistent with the fact that except for large clients and important risks the primary insurance markets tend to have a national dimension even if they are mainly served by famous multinational insurance groups. (European Commission, 2007). On these data, we can see that the differences in the market share of insurance brokers do not depend on the EU membership of the country.

There are also differences between brokers depending on the category of insurance.

Thus, table 2 shows the importance of brokers on the life insurance market, respectively general insurance market for some of the European insurance markets highlighting the significant differences regarding the involvement of brokers on the two categories of markets.

Table no. 2

\section{Market share of broker channel on life insurance and on general insurance markets} in European countries

\begin{tabular}{|l|r|r|r|r|r|r|}
\hline \multirow{2}{*}{ Country } & \multicolumn{2}{|c|}{$\mathbf{2 0 0 7}$} & \multicolumn{2}{c|}{$\mathbf{2 0 0 8}$} & \multicolumn{2}{c|}{$\mathbf{2 0 0 9}$} \\
\cline { 2 - 7 } & $\begin{array}{c}\text { Life } \\
\text { insurance }\end{array}$ & $\begin{array}{c}\text { General } \\
\text { insurance }\end{array}$ & $\begin{array}{c}\text { Life } \\
\text { insurance }\end{array}$ & $\begin{array}{c}\text { General } \\
\text { insurance }\end{array}$ & $\begin{array}{c}\text { Life } \\
\text { insurance }\end{array}$ & $\begin{array}{c}\text { General } \\
\text { insurance }\end{array}$ \\
\hline Austria & $15,6 \%$ & $37,6 \%$ & $17,5 \%$ & $37,8 \%$ & $13,4 \%$ & $39,4 \%$ \\
\hline Belgium & $33,4 \%$ & $62,6 \%$ & $33,3 \%$ & $62,3 \%$ & $33,0 \%$ & $61,8 \%$ \\
\hline Bulgaria & $22,1 \%$ & $32,3 \%$ & $24,9 \%$ & $39,7 \%$ & $22,6 \%$ & $45,7 \%$ \\
\hline Germany & n.a & $23,3 \%$ & $19,6 \%$ & $24,4 \%$ & n.a. & n.a \\
\hline Spain & $6,7 \%$ & $26,7 \%$ & $8,1 \%$ & $26,7 \%$ & n.a. & n.a. \\
\hline France & $13,0 \%$ & $18,0 \%$ & $14,0 \%$ & $18,0 \%$ & $14,0 \%$ & $18,0 \%$ \\
\hline Croatia & $0,4 \%$ & $2,3 \%$ & $1,5 \%$ & $2,2 \%$ & $1,5 \%$ & $2,2 \%$ \\
\hline Ireland & $40,9 \%$ & $59,3 \%$ & $45,2 \%$ & $59,2 \%$ & $50,7 \%$ & $58,2 \%$ \\
\hline Italy & $1,4 \%$ & $7,4 \%$ & $1,5 \%$ & $7,6 \%$ & $1,0 \%$ & $7,9 \%$ \\
\hline Lithuania & $13,0 \%$ & $36,0 \%$ & n.a. & n.a. & n.a. & n.a. \\
\hline Malta & $2,8 \%$ & n.a. & $3,2 \%$ & $22,5 \%$ & $3,0 \%$ & $21,4 \%$ \\
\hline Poland & $2,4 \%$ & $14,2 \%$ & $1,6 \%$ & $14,3 \%$ & $4,7 \%$ & $16,5 \%$ \\
\hline
\end{tabular}




\begin{tabular}{|l|r|r|r|r|r|r|}
\hline Portugal & $1,0 \%$ & $16,4 \%$ & $1,3 \%$ & $16,9 \%$ & $1,0 \%$ & $19,6 \%$ \\
\hline Slovenia & $16,3 \%$ & $9,8 \%$ & $17,6 \%$ & $11,2 \%$ & $9,6 \%$ & $4,6 \%$ \\
\hline Turkey & $0,9 \%$ & $9,7 \%$ & $4,7 \%$ & $10,1 \%$ & $0,9 \%$ & $11,3 \%$ \\
\hline Great Britain & $73,4 \%$ & $54,4 \%$ & $78,7 \%$ & $56,4 \%$ & $71,6 \%$ & $56,9 \%$ \\
\hline
\end{tabular}

Source: CEA statistics - http://www.cea.eu/index.php/facts-figures/statistical-series/market-operators, data not available for the year 2010

In most countries (except Croatia, Italy, Slovenia and Turkey) we can see the great importance brokers have on the general insurance market. In this case, as an effect of products' diversity, covered risks and pricing methods the involvement of brokers help identify the most suitable appropriate product and obtaining the lowest price possible.

Based on data provided in Table 1 and Table 2, the maintaining of the high share in Great Britain and Ireland, but also in Belgium, as it was highlighted in the Report on insurance industry in the EU issued in 2007, was confirmed; Bulgaria was also added to these countries. Based on the same report we can say that the brokers are the most important distribution channel for commercial insurance in the EU25.

Regarding the analysis of the Romanian insurance brokerage market, it highlights the significant progress registered after 2000, when this activity was regulated more appropriately. In 2008-2010 the activity of insurance brokers experienced the effects of the financial and economic crisis affecting the entire insurance market.

Table no. 3 shows the evolution of the gross premiums subscribed by brokers compared with the evolution of the gross premiums subscribed by insurers for both the overall market and for the two main categories of insurance: general, and life insurance.

Table no. 3

The brokers' activity on the Romanian insurance market

\begin{tabular}{|l|r|r|r|}
\hline Indicators & \multicolumn{1}{c|}{$\mathbf{2 0 0 8}$} & \multicolumn{1}{c|}{$\mathbf{2 0 0 9}$} & \multicolumn{1}{c|}{$\mathbf{2 0 1 0}$} \\
\hline Total subscribed gross premiums, including (mil. lei): & 8936,28 & 8869,75 & 8305,4 \\
\hline - general insurance (mil.lei) & 7068,17 & 7241,58 & 6639,73 \\
\hline - life insurance (mil. lei) & 1868,11 & 1628,16 & 1665,67 \\
\hline $\begin{array}{l}\text { Total gross premiums subscribed by brokers, including } \\
\text { (mil.lei): }\end{array}$ & 2704,6 & 3211,37 & 3199,71 \\
\hline - general insurance (mil.lei) & 2553,04 & 3114,3 & 3111,84 \\
\hline - life insurance (mil.lei) & 153,75 & 97,07 & 87,88 \\
\hline The share of brokers on the insurance market - \% & 30,27 & 36,21 & 38,53 \\
\hline The share of brokers on the general insurance market - \% & 36,12 & 43,01 & 46,87 \\
\hline The share of brokers on the life insurance market - \% & 8,23 & 5,96 & 5,28 \\
\hline
\end{tabular}

Source: author's processing based on data from ISC Reports 2008-2010, InsuranceProfile magazine, issue 1/2009.

It must be noted that on the period of 2008-2010, the evolution of insurance market was descending, as effect of the reduced activity in constructions, of decreasing of the industrial investments and of the credit transactions, of the renegotiations of insurance conditions by the clients to reduce paid premiums and of the renunciation of covering some of the risks by the clients. Also, some companies give up the insurances for the employees. In this context, the insurance brokerage market (in nominal terms) grew up in 2009 and remains about the same level in 2010. Putting together these facts, we can see that, as the effect of crises on insurance market, an important share of clients moved from direct insurers to brokers.

In terms of its share in the insurance activity, the evolution of brokerage activity on the Romanian insurance market has experienced a continuous growth. Thus, we see that Romania is among the countries where the share of brokerage is significant, this share being over $30 \%$ in all three analyzed years and the growing trend was constant. On the other hand, the importance of 
brokerage on general insurance market is much greater (especially for auto and buildings insurance), the discrepancy between the size of the brokerage for general insurance and life insurance being very significant $(5,28 \%$ for life insurance, $46,87 \%$ for general insurance in 2010$)$, with a divergent evolution trend - growth for general insurance, reduction for life insurance.

This type of evolution is the result of divergent developments reflected in table 4 . From the shown data we can observe the evolution of the insurance market as a whole and based on the two components, compared with the brokerage insurance market. Thus, after the year 2008 has led to an increase of both markets, with a particularly strong increase of both components of the brokerage market, the year 2009 revealed some differences in the evolution of the evolution of the two market categories (insurance, respectively of brokerage in insurance). Therefore, we can see how, despite the reducing of insurance market both in nominal and real terms, the market of insurance brokerage has seen a nominal advance of $18,74 \%$ (the real advance was $13,36 \%$ ), based on the important advance $-21,98 \%$ in nominal terms, respectively $16,46 \%$ in real terms of the brokerage in the field of general insurance, while the market of general insurance although it recorded a nominal growth of $2,45 \%$, war reduced in real terms with over $2 \%$. The same trends were recorded on the markets of general insurance but even here the reduction percentage was significantly different $(12,84 \%$ on the insurance market, respectively $36,87 \%$ on the brokerage market - in nominal terms), the explanation being the decrease in the activity of some life insurance brokers as the overall negative economic context the focus on this field may led to important efforts with minimum results which would significantly affect the financial results, the balance and even the brokers existence (especially the small ones).

The positive evolution of brokerage on the general insurance market in terms of huge reduction of the real estate, auto leasing markets can be explained by the orientation of consumers of insurance products towards brokers in order to obtain the best price and insurance products, but also by greater attention paid by the brokers to retail as the behaviour of corporate clients regarding the purchase of cars has changed (they postpone the decision of purchasing a new car), the degree of using them (they extend the time they use the cars), the reduction to minimum the insurance expenses for unused cars. In addition, brokerage companies tried to develop the segment of direct clients in order to compensate the reduction of policies signed by leasing clients.

Tabel no. 4

The evolution of insurance market compared with the evolution of insurance brokerage market

\begin{tabular}{|l|r|r|r|r|r|r|}
\hline \multirow{2}{*}{ Indicators } & \multicolumn{2}{|c|}{2008} & \multicolumn{2}{c|}{2009} & \multicolumn{2}{c|}{2010} \\
\cline { 2 - 7 } & $\begin{array}{c}\text { Nominal } \\
\text { growth } \\
(\%)\end{array}$ & $\begin{array}{c}\text { Real } \\
\text { growth } \\
(\%)\end{array}$ & $\begin{array}{c}\text { Nominal } \\
\text { growth } \\
(\%)\end{array}$ & $\begin{array}{c}\text { Real } \\
\text { growth } \\
(\%)\end{array}$ & $\begin{array}{c}\text { Nominal } \\
\text { growth } \\
(\%)\end{array}$ & $\begin{array}{c}\text { Real } \\
\text { growth } \\
(\%)\end{array}$ \\
\hline $\begin{array}{l}\text { The growth of gross premiums } \\
\text { subscribed by brokers, } \\
\text { including: }\end{array}$ & 72,43 & 62,21 & 18,74 & 13,36 & $-0,36$ & $-7,71$ \\
\hline - general insurance & 70,46 & 60,36 & 21,98 & 16,46 & $-0,08$ & $-7,45$ \\
\hline - life insurance & 117,13 & 104,26 & $-36,87$ & $-39,72$ & $-9,47$ & $-16,14$ \\
\hline $\begin{array}{l}\text { The growth of subscribed gross } \\
\text { premiums: }\end{array}$ & 24,53 & 17,15 & $-0,74$ & $-5,24$ & $-6,36$ & $-13,27$ \\
\hline - general insurance & 23,42 & 16,11 & 2,45 & $-2,18$ & $-8,31$ & $-15,07$ \\
\hline - life insurance & 28,92 & 21,28 & $-12,84$ & $-16,79$ & 2,30 & $-5,24$ \\
\hline
\end{tabular}

Source: author's processing based on data from ISC Reports 2008-2010, InsuranceProfile magazine, issue 1/2009, The National Institute of Statistics

The year 2010 had again contradictory tendencies between two categories of markets. Thus, although both markets had declines in nominal and real terms, they were much lower for the 
brokerage market than for the insurance market $(0,36 \%$ to $6,36 \%$ in nominal terms). Regarding the market's structure, there is a smaller reduction for general insurance brokerage market than the general insurance market ( $0,08 \%$ to $8,31 \%$ in nominal terms), and this has essentially influenced the insurance market. However, for life insurance the tendencies are again divergent if we consider the nominal terms: the insurance market grew by $2,30 \%$, while the brokerage market recorded a significant decline $-9,47 \%$, but in real term both markets have declined. Such an evolution for life insurance was based on the stabilization of the financial markets, while the decline of the brokerage for general insurance was a result of the degradation of the overall economic situation and the reducing of incomes.

Regarding the brokerage market's structure in terms of the market share of participants we analyzed the degree of market concentration.

Thus, we emphasized the share of the first 10, respectively 20 insurance brokers during 2008-2010, and data is presented in table 5.

Table no. 5

The degree of the brokerage market's concentration on the Romanian insurance market during 2008-2010

\begin{tabular}{|c|c|c|c|c|c|c|}
\hline & \multicolumn{2}{|c|}{2008} & \multicolumn{2}{|c|}{2009} & \multicolumn{2}{|c|}{2010} \\
\hline & $\mathbf{N}=\mathbf{1 0}$ & $\mathbf{N}=\mathbf{2 0}$ & $\mathrm{N}=10$ & $\mathbf{N}=\mathbf{2 0}$ & $\mathrm{N}=10$ & $\mathbf{N}=\mathbf{2 0}$ \\
\hline $\begin{array}{l}\text { Total gross premiums subscribed by the } \\
\text { first } N \text { (10 or } 20) \text { brokers, including (mil. } \\
\text { lei): }\end{array}$ & 1216,17 & 1520,51 & 1446,39 & 1853,25 & 1262,27 & 1690,33 \\
\hline - general insurance (mil. lei) & 1210,58 & 1453,59 & 1438,06 & 1820,51 & 1253,32 & 1678,33 \\
\hline - life insurance (mil. lei) & 5,09 & 66,39 & 8,06 & 32,46 & 8,93 & 11,96 \\
\hline $\begin{array}{l}\text { Total gross premiums subscribed by } \\
\text { brokers, including (mil. lei): }\end{array}$ & \multicolumn{2}{|c|}{2704,59} & \multicolumn{2}{|c|}{3211,37} & \multicolumn{2}{|c|}{3199,71} \\
\hline - general insurance (mil. lei) & \multicolumn{2}{|c|}{2553,04} & \multicolumn{2}{|c|}{3114,3} & \multicolumn{2}{|c|}{3111,84} \\
\hline - life insurance (mil. lei) & \multicolumn{2}{|c|}{153,75} & \multicolumn{2}{|c|}{97,07} & \multicolumn{2}{|c|}{87,88} \\
\hline $\begin{array}{l}\text { The share of gross premiums subscribed } \\
\text { by the first } \mathrm{N}(10 \text { or } 20) \text { brokers in the } \\
\text { gross premiums subscribed by brokers - } \\
\%\end{array}$ & 44,97 & 56,22 & 45,04 & 57,71 & 39,45 & 52,83 \\
\hline - general insurance $(\%)$ & 47,42 & 56,94 & 46,18 & 58,46 & 40,28 & 53,93 \\
\hline - life insurance $(\%)$ & 3,31 & 43,18 & 8,30 & 33,43 & 10,16 & 13,61 \\
\hline
\end{tabular}

Source: author's processing based on data from ISC Reports 2008-2010, InsuranceProfile magazine, issue 1/2010 for data from 2008

Based on table 5 we can see that the insurance brokerage market is highly concentrated. Thus, although the number of brokers was over 400 in each of the three analyzed years, the share of the first 20 insurance brokers in the total of brokerage market is over $50 \%$ in each of these years, and the other brokers have a market share less than $1 \%$. Moreover, the first 10 brokers have a summed rate of approximately 45\% in 2008 and 2009, and approximately $40 \%$ in 2010 which stresses that brokers situated on 11-20 positions are actually medium to small rather than large brokers. The reduction of the summed market share of the first 10 brokers is mainly due to the decrease of corporate clients as well as those provided by the leasing industry.

The important differences can also be noticed if we refer to the two branches of insurance: general insurance and life insurance. Thus, if for general insurance the tendency is the same as the overall brokerage market (increases of the market share in 2008 and 2009, decreases in 2010), for life insurance there is a continuous growing tendency of the share of the first 10 brokers while for the first 20 brokers there is a decrease tendency. Such an evolution is explained by the fact that the market began to be strongly dominated by brokers whose activity is on the general insurance market as a result of the significant reductions of life insurance subscriptions through brokers, so that a part 
of the brokers having a major activity on the life insurance market are no longer found in the first 20 companies, the only brokers still present in this top being those with an important activity on the general insurance market. The increase of the first 10 brokers' share for life insurance represents the result of maintaining the approximate volume of subscribed gross premiums along with the significant decline of the life insurance within brokerage market.

Table no. 6

The structure of the insurance brokerage market

\begin{tabular}{|l|r|r|r|}
\hline Indicators & $\mathbf{2 0 0 8}$ & $\mathbf{2 0 0 9}$ & $\mathbf{2 0 1 0}$ \\
\hline $\begin{array}{l}\text { Total gross premiums subscribed by the first 10 brokers, } \\
\text { including: }\end{array}$ & $100 \%$ & $100 \%$ & $100 \%$ \\
\hline - general insurance & $99,55 \%$ & $99,42 \%$ & $99,29 \%$ \\
\hline - life insurance & $0,45 \%$ & $0,56 \%$ & $0,71 \%$ \\
\hline $\begin{array}{l}\text { Total gross premiums subscribed by the first 20 brokers, } \\
\text { including: }\end{array}$ & $100 \%$ & $100 \%$ & $100 \%$ \\
\hline - general insurance & $95,61 \%$ & $98,25 \%$ & $99,29 \%$ \\
\hline - life insurance & $4,39 \%$ & $1,75 \%$ & $0,71 \%$ \\
\hline Total gross premiums subscribed by brokers, inluding: & $100 \%$ & $100 \%$ & $100 \%$ \\
\hline - general insurance & $94,39 \%$ & $96,98 \%$ & $97,25 \%$ \\
\hline - life insurance & $5,68 \%$ & $3,02 \%$ & $2,75 \%$ \\
\hline
\end{tabular}

Source: author's processing based on data from ISC Reports 2008-2010.

Such a conclusion is supported by the data in table 6 which highlights the decrease of life insurances in the brokerage companies' portfolio and of the first 20 brokerage companies, but also the almost insignificant increase in the share of gross premiums subscribed from life insurances in the portfolio of the first 10 brokers. Additional, it should be noted that the share of life insurances in the portfolio of the 10, respectively 20 brokers in 2010 is identical suggesting the absence form top 20 of the brokers specialized in life insurance.

Regarding the structure of the gross intermediated premiums we need to particularly stress on the importance of auto insurance brokerage because, according to data provided by the specialized publication Insurance Profile, in 2009, they represented $45 \%$ of the CASCO insurance portfolio and 32\% MTPL insurance, and in $2010-79 \%$ (CASCO and MTPL). Another important insurance category in the brokers' activity is represented by the fire insurance - 9\% in 2009, respectively $10 \%$ in 2010 . As a consequence of this market structure, the leader of the brokerage market is the same brokerage company occupying the first position on the auto insurance market.

In terms of the role insurance brokers have on the Romanian market, it is especially reflected in finding the best deals for policyholders. This is also reflected by the structure of the brokers' incomes within which those resulting from insurance contracts negotiations are very important; the incomes resulting from other activities (commissioner of damage, risk inspections, damage adjustments, etc.) occupy a minor place in the structure of the incomes of these companies, as shown in table 7.

Table no. 7

The structure of Romanian brokers' incomes during 2008-2010

\begin{tabular}{|c|c|c|c|c|c|c|c|c|c|c|c|}
\hline \multirow[t]{2}{*}{ Year } & \multirow{2}{*}{$\begin{array}{c}\text { Total } \\
\text { incomes } \\
\text { Absolute } \\
\text { value } \\
\text { (mil. lei) }\end{array}$} & \multicolumn{2}{|c|}{$\begin{array}{l}\text { Incomes resulted } \\
\text { from negotiating } \\
\text { the insurance } \\
\text { contracts }\end{array}$} & \multicolumn{2}{|c|}{$\begin{array}{l}\text { Incomes from } \\
\text { risk inspections }\end{array}$} & \multicolumn{2}{|c|}{$\begin{array}{l}\text { Incomes from } \\
\text { damage } \\
\text { adjustments }\end{array}$} & \multicolumn{2}{|c|}{$\begin{array}{c}\text { Incomes from } \\
\text { commissioner of } \\
\text { damage }\end{array}$} & \multicolumn{2}{|c|}{ Other incomes } \\
\hline & & $\begin{array}{l}\text { Absolute } \\
\text { value } \\
\text { (mil. lei) } \\
\end{array}$ & $\%$ & $\begin{array}{c}\text { Absolute } \\
\text { value } \\
\text { (mil. lei) } \\
\end{array}$ & $\%$ & $\begin{array}{c}\text { Absolute } \\
\text { value } \\
\text { (mil. lei) } \\
\end{array}$ & $\%$ & $\begin{array}{l}\text { Absolute } \\
\text { value } \\
\text { (mil. lei) }\end{array}$ & $\%$ & $\begin{array}{c}\text { Absolute } \\
\text { value } \\
\text { (mil. lei) } \\
\end{array}$ & $\%$ \\
\hline 2008 & 488,53 & 472,35 & 96,69 & 0,17 & 0,03 & 7,14 & 1,46 & 0,43 & 0,09 & 8,44 & 1,73 \\
\hline 2009 & 504,69 & 479,53 & 95,01 & 1,74 & 0,34 & 11,53 & 2,28 & 2,62 & 0,52 & 9,27 & 1,84 \\
\hline 2010 & 535,77 & 507,3 & 94,69 & 4,73 & 0,88 & 11,7 & 2,18 & 3,14 & 0,59 & 8,90 & 1,66 \\
\hline
\end{tabular}

Source: ISC Reports 2008-2010 and author's processing based on data from ISC Reports 2008-2010. 
In terms of the efficiency of brokerage activity, we can see that on the whole brokerage market, the result was positive in all three analyzed years, but the tendency was to reduce its size as it shown by the data in table 7 .

It is noted that in each of the three analyzed years, over $60 \%$ of the brokers who have submitted reports to the Insurance Supervisory Commission had a profit, while over $30 \%$ had losses. However, it should be noted that in 2009 was recorded the largest number of companies which had losses although the accumulated loss was relatively close to the one in the previous year. As a result of the crisis, the brokerage companies have adapted their activities so that in 2010 the number of profit companies increased to 55 companies and the number of companies with losses decreased by 10 companies. Under these circumstances, the cumulative loss of companies with losses has decreased.

Table no. 8

The results of the Romanian brokerage market during $2008-2010$

\begin{tabular}{|c|c|c|c|c|c|c|c|c|c|}
\hline Year & $\begin{array}{c}\text { No. } \\
\text { brokers }\end{array}$ & $\begin{array}{c}\text { No. } \\
\text { Reports } \\
\text { of brokers }\end{array}$ & \multicolumn{2}{|c|}{$\begin{array}{c}\text { Brokers who } \\
\text { registered profit }\end{array}$} & $\begin{array}{c}\text { Cumulated } \\
\text { profit } \\
\text { (mil. Lei) }\end{array}$ & \multicolumn{2}{|c|}{$\begin{array}{c}\text { Brokers who } \\
\text { registered losses }\end{array}$} & $\begin{array}{c}\text { Cumulated } \\
\text { loss } \\
\text { (mil. lei) }\end{array}$ & $\begin{array}{c}\text { Cumulated } \\
\text { result } \\
\text { (mil. lei) }\end{array}$ \\
\hline 2008 & 403 & 403 & 273 & $67,74 \%$ & 169,6 & 130 & $32,26 \%$ & 20,69 & 148,91 \\
\hline 2009 & 482 & 437 & 266 & $60,87 \%$ & 172,61 & 171 & $39,13 \%$ & 27,31 & 145,3 \\
\hline 2010 & 567 & 493 & 321 & $65,11 \%$ & 151,52 & 161 & $32,66 \%$ & 21,16 & 130,36 \\
\hline
\end{tabular}

Source: author's processing based on data from ISC Reports 2008-2010.

Such an evolution reflects a trend of financial optimization of the politics of brokerage companies, an adaptation made by general or specific means.

In the category of general means we have those aiming at lessening the expenses (the main targeted groups were protocol, travel, rent, advertising expenses and incomes) or revenue growth (due mainly to renegotiating the commissions, to focusing on retail activities, on/line sales development), while among specific means we have the expansion of collaborations with insurers, obtaining additional facilities from insurers, limiting the credit for clients, stopping the purchases, expanding the network of collaborators paid based on commission, staff investments, costs for market research.

Table no. 9

The efficiency of insurance subscription activity performed by brokers

\begin{tabular}{|c|r|r|r|}
\hline Year & $\begin{array}{c}\text { Revenue by negotiating } \\
\text { the contracts } \\
\text { (mil. lei) }\end{array}$ & $\begin{array}{c}\text { Gross premiums subscribed } \\
\text { by the brokerage market } \\
\text { (mil. lei) }\end{array}$ & $\begin{array}{c}\text { Revenue /100 lei } \\
\text { gross subscribed } \\
\text { premiums }\end{array}$ \\
\hline $\mathbf{2 0 0 8}$ & 472,35 & 2704,59 & 17,46 \\
\hline $\mathbf{2 0 0 9}$ & 479,53 & 3211,37 & 14,93 \\
\hline $\mathbf{2 0 1 0}$ & 507,3 & 3199,71 & 15,85 \\
\hline
\end{tabular}

Source: ISC Reports 2008-2010 and author's processing based on data from ISC Reports 2008-2010.

Changing the view regarding the subscription politics is observed through the relation between the earned revenue as a result of negotiating the contracts and the gross subscribed premiums whose evolution reflects the shifting of brokers' attention from aspects referring to market share to aspects referring to revenues. However, such a trend may also emphasize a negative aspect regarding the quality of intermediation since it can be the result of subscripting more expensive products or for which the broker cashes a higher commission. The current lack of data does not allow us to formulate a clear and objective opinion on this matter, but a future study may reveal more precisely the cause of such a result.

As for the analysis of public perception on the insurance brokerage activity and on the insurers brokers' importance, we will highlight some data from a study conducted in early 2011 by Romanian Institute for Valuation and Strategy (RIVS) on a sample of 864 persons aged between 18 
and 55 years in urban areas. This study showed that in urban areas the brokers are known by $78 \%$ of the population, $56 \%$ of the population associating them with the field of insurance. According to the study, $89 \%$ of the population questioned considers that insurance consultancy is needed and $72 \%$ of population thinks that there is necessary to be intermediaries between insurers and clients. Although $69 \%$ of the respondents have a good impression about the insurance brokers, $52 \%$ of population has poor information about brokers. As a result, the public perception of brokers still shows negative aspects, namely $58 \%$ of the questioned population said that the existence of brokers leads to an increase of insurance costs, the effect of this perception being that only $38 \%$ of the respondents would opt for consultancy provided by brokers, while over $50 \%$ would purchase insurance products from insurance agents. These perceptions show that, unlike Cummings and Doherty (2006) suggested for the US market, the clients' of the Romanian insurance brokerage market is more preoccupied by the price of the insurance products and after that on the quality.

The results of this study show that on the Romanian market there is an insufficient education in the field of insurance. Therefore, a key aspect that could lead to a consolidation or even growth of the market is that of brokers' involvement in insurance education campaigns through which they bring awareness to potential clients about the benefits of concluding insurance policies through brokers. But these campaigns must be accompanied by the continuous improvement of broker's agents' qualification.

Another negative perception of the population regarding the insurance brokers' activity reflect the so called "brokers' opportunism", as reflected by Tajudeen (2011). So, 51\% of the persons think that the brokers are more interested in own profit than in the well being of the client.

\section{Conclusions}

Based on the presented and analyzed data we can see the increased importance insurance brokers have on the Romanian insurance market.

Faced with the economic crisis, the insurance brokers were able to adapt themselves to new conditions quicker than the insurance companies, therefore the evolution of gross intermediated premiums registered a more favorable trend than the evolution of the gross premiums subscribed on the insurance market. This result was also obtained as a consequence of a more significant presence in the territory, which led to making insurance consumers aware of the role the insurance broker has - providing consultancy for identifying the most suitable product in terms or coverage/price. Thus, in the context of the financial and economic crisis the tendency of the clients is to choose cheaper and less comprehensive products so that brokers play an important role in getting for clients products that have an adequate protection at competitive prices as a result of their knowledge and higher negotiation power. In addition, the use of brokers for insurance subscription led to the highlighting, yet smaller, of their role as partners of the client, offering its post-sales services regarding the indemnity.

Another opportunity offered by crisis for insurance brokers is the awareness of the people regarding the importance of having insurance for properties, for accidents, for liabilities and, according to the RIVS study mentioned before, the perception of brokers as specialists that offer adequate solutions to the consumers' needs so the trend of the insurance brokerage could grow in the future.

The main strategic guidelines which assured this adaptation to the new economic conditions aimed at territorial expansion through brokerage agents, affecting the structure of the clients' portfolio this changing towards a growing number of retail clients as well as the attempts to integrate the electronic sales system of insurers within a common platform so as to reduce the time between the client's request and the purveyance of an adequate offer. This tendency is a good one, as the RIVS study found that $62 \%$ of the population questioned by the study obtains information from friends. 
Another challenge for insurance brokers is given by the need for training of those working in this field. In our opinion, the introduction of this requirement will result in a higher professionalization of the market as an outcome of additional training and of elimination from the market of those who will not do this. The most important qualities that the brokers' agents must have are to have good information and to be competent. So, under the circumstance of a favorable evolution of the economy, this can lead to an increase of the degree of insurances' penetration as a result of increased consumer confidence in the quality of advice provided by insurance brokers.

A trend that began to manifest itself and that we believe will continue with a higher speed is the development of sales via Internet. This way the expansion of the activity at national level could be achieved without additional costs comparable with setting up a network of people in major cities. In addition, the sale via Internet has the advantage that it can be done at any time of the day.

We also have to highlight the challenges that may arise due to changes in the legal framework; currently, at the EU level, is under discussion the change of the Directive regarding the insurance intermediation. Following the start of consultations regarding the document recommending the change of the Directive, the European Commission has summarized the main received observations. They are considering aspects regarding consumers' protection, the conflict of interest management and transparency, the effectiveness of cross-bordering insurance, the required level of training, the distribution of PRIPs.

Therefore, it is noted that the insurance brokerage will face some challenges, but this can be a starting point for achieving high quality activities and an increase of the brokerage market.

\section{References}

1. Braunwarth K., Buhl H.U., Kaiser M., Krammer A., Roglinger M., Wehrmann A., 2009. The EU Insurance Mediation Directive - Bureaucracy or Opportunity?, in Enterprise Applications and Services in the Finance Industry, 4th International Workshop, FinanceCom 2008, Paris, France, December 13, 2008, Springer-Verlag Berlin Heidelberg;

2. Cummings and Doherty, 2006. The Economics Of Insurance Intermediaries, Journal of Risk \& Insurance, Vol. 73, No. 3, pp. 359-396;

3. Dănulețiu D., Dănulețiu A., 2008. Insurance Brokerage In Romania, the Annals of University of Oradea, economic sciences, 2008, pp. 728-733;

4. Eckardt M., 2002. Agent and Broker Intermediaries in Insurance Markets - An Empirical Analysis of Market Outcomes, Thünen-Series of Applied Economic Theory Working Paper, no. 34, Rostock, Rostock University, available online at http://static.twoday.net/fitzsimons/files/Text6.pdf;

5. Eckardt M., 2007. Insurance Intermediation - An Economic Analysis of the Information Services Market. Physica, Heidelberg;

6. Eckardt M., Rathke-Doppner 2008. The Quality of Insurance Intermediary Services Empirical Evidence for Germany, Andrássy Working Paper Series No. XXV, available online at http://www.andrassyuni.eu/upload/File/Forschung/Andrassy \%20Working \%20Papers/ awsp25eckardtraethke.pdf;

7. Focht U., Richter A., Schiller J., (2009), Intermediation and Matching in Insurance Markets, University of Hohenheim, Center for Research on Innovation and Services Working Papers, online la adresa http://ideas.repec.org/p/zbw/fziddp/200904.html;

8. Gavriletea M., 2008. Particularity of selling insurance for Romanian insurance companies, Interdisciplinary management research, IV, pp. 264-274;

9. Mass P., 2010. How Insurance Brokers Create Value-A Functional Approach, Risk Management and Insurance Review, 13 (1), pp. 1-20;

10. Tajudeen Olalekan Yusuf 2010. Brokers and the control of postcontractual opportunism in the Nigerian insurance market, Journal of Financial Crime, Vol. 17 Iss: 2, pp.223 - 239; 
11. European Commission, 2007. Business insurance sector inquiry, Interim report, online at: http://ec.europa.eu/competition/sectors/financial_services/inquiries/interim_report_2401200 7.pdf;

12. CEA, 2010. Insurance Distribution Channels in Europe, CEA Statistics, no.37, October;

13. BIPAR, 2010. Insurance intermediaries in Europe, report to BIPAR prepared by London Economics, online at: http://www.bipar.eu/en/insurance-intermediaries/economic-data;

14. Swiss Re, 2004, Commercial insurance and reinsurance brokerage - love thy middleman, SIGMA 2/2004;

15. EU insurance mediation directive 2002/92/CE, available online at: http://eurlex.europa.eu/LexUriServ/LexUriServ.do?uri=CELEX:32002L0092:EN:NOT;

16. Romanian Insurance Supervising Commission Reports for the years 2008-2010;

17. United Nations Conference on Trade and Development, 2007. Trade and development aspects of insurance services and regulatory frameworks, New York and Geneva.

18. Romanian Institute for Valuation and Strategy, Perceptions regarding insurance brokerage, available online at http://www.kundenbroker.ro/node/3 